Article

\title{
Assessing the Potential Interactions between Cellular miRNA and Arboviral Genomic RNA in the Yellow Fever Mosquito, Aedes aegypti
}

\author{
Pei-Shi Yen ${ }^{1, *}$, Chun-Hong Chen ${ }^{2,3}$, Vattipally Sreenu ${ }^{4}\left(\mathbb{D}\right.$, Alain Kohl ${ }^{4}$ and \\ Anna-Bella Failloux 1,* \\ 1 Unit of Arboviruses and Insect Vectors, Department of Virology, Institut Pasteur, 75015 Paris, France \\ 2 National Health Research Institutes, National Institute of Infectious Diseases and Vaccinology, Miaoli 35053, \\ Taiwan; chunhong@nhri.org.tw \\ 3 National Mosquito-Borne Diseases Control Research Center, Miaoli 35053, Taiwan \\ 4 MRC-University of Glasgow Centre for Virus Research, Glasgow G61 1QH, Scotland, UK; \\ Sreenu.Vattipally@glasgow.ac.uk (V.S.); Alain.Kohl@glasgow.ac.uk (A.K.) \\ * Correspondence: pei-shi.yen@pasteur.fr (P.-S.Y.); anna-bella.failloux@pasteur.fr (A.-B.F.)
}

Received: 2 May 2019; Accepted: 5 June 2019; Published: 10 June 2019

\begin{abstract}
Although the role of exogenous small interfering RNA (siRNA) and P-element induced wimpy testis (PIWI)-interacting RNA (piRNA) pathways in mosquito antiviral immunity is increasingly better understood, there is still little knowledge regarding the role of mosquito cellular microRNA (miRNA). Identifying direct interactions between the mosquito miRNAs and the RNA genome of arboviruses and choosing the relevant miRNA candidates to explore resulting antiviral mechanisms are critical. Here, we carried out genomic analyses to identify Aedes aegypti miRNAs that potentially interact with various lineages and genotypes of chikungunya, dengue, and Zika viruses. By using prediction tools with distinct algorithms, several miRNA binding sites were commonly found within different genotypes/and or lineages of each arbovirus. We further analyzed those miRNAs that could target more than one arbovirus, required a low energy threshold to form miRNA-viralRNA (vRNA) complexes, and predicted potential RNA structures using RNAhybrid software. We predicted miRNA candidates that might participate in regulating arboviral replication in Ae. aegypti. Even without any experimental validation, which should be done as a next step, this study can shed further light on the role of miRNA in mosquito innate immunity and targets for future studies.
\end{abstract}

Keywords: Aedes aegypti; arboviruses; chikungunya; dengue; Zika; miRNA

\section{Importance}

The role of the small interfering RNA (siRNA) and P-element induced wimpy testis (PIWI)-interacting RNA (piRNA) pathways in controlling virus infections in mosquitoes has been extensively studied and are considered to be a major part of the antiviral innate immune response. Although several studies have indicated that cellular microRNAs (miRNA) are involved in mosquito antiviral immunity, the miRNA-viralRNA (vRNA) direct interaction and its effect on virus replication in mosquitoes are still unclear. The cellular miRNAs of the mosquito Aedes aegypti, a vector for many arboviral diseases, may directly interact with three major arboviruses: chikungunya, dengue, and Zika viruses. By using the miRanda and TargetSpy tools (http://bioinfo5.ugr.es/srnatoolbox), several miRNAs were predicted to have potential binding sites that are common to multiple viral genotypes or lineages. Further analysis was carried out on miRNA-vRNA interactions that required a low energy threshold to form a complex. This study shows a broad picture of possible interactions between 
mosquito cellular miRNAs and the viral RNA of different genotypes/lineages of arboviruses, providing a list of mosquito cellular miRNAs candidates for experimental validations in future studies.

\section{Introduction}

Emerging and reemerging arthropod-borne viruses (arboviruses) are spreading globally in recent decades [1]. Arboviruses usually have RNA genomes, including positive-strand RNA alphaviruses (genus Alphavirus, family Togaviridae) and flaviviruses (genus Flavivirus, family Flaviviridae) [2]. The evolution of mosquito-borne RNA viruses and the complex interplay between the vector, the host, and the virus can shape arboviral emergence and re-emergence [3,4]. Infection of the arthropod midgut epithelial cells occurs following ingestion of a viremic blood meal; the ingested virus must disseminate through internal tissues and organs before reaching the salivary glands to be transmitted. Thus the virus has to overcome a series of tissue barriers before being secreted in mosquito saliva when it takes its next blood meal [5]. Each barrier has different tissue-specific immune properties, which, once triggered by viral infection, may affect the mosquito's overall vector competence [6]. Immune responses to arboviruses involve different pathways, but key roles are played by small RNA/RNA interference (RNAi) pathways [7-10], which have been shown to be a major innate antiviral immune response in mosquitoes against arboviruses of all families [11,12].

Mosquitoes have three major types of small RNA pathways and associated molecules: the siRNA, piRNA, and miRNA pathways [9,11-13]. The siRNA antiviral immunity of mosquitoes was triggered by exogenous long double-stranded RNA (dsRNA) molecules, which are produced during viral replication. These dsRNAs are recognized by several siRNA biogenesis components and processed into predominantly 21 nucleotides (nt) mature viral siRNAs (vsiRNA). These vsiRNAs are loaded into the multi-protein RNA-Induced Silencing Complex (RISC), which contains the endonuclease Argonaute-2 (Ago-2). The viral RNA genome (or mRNA) containing complementary sequence could be targeted by Ago-2, trigger the cleavage of the target RNA and consequently, reduce the virus replication. These results have stressed the role of exogenous RNAi pathway in controlling viral replication [14-18].

Accumulating data suggest that the piRNA pathway is also involved in mosquito RNAi antiviral immunity [12,19-23], although the effector and effector mechanism are unclear. piRNAs are 24-30 nt in size and produced in a Dicer-independent manner. piRNA molecules interact with Argonaute-3 (Ago-3) and Piwi proteins in a so-called "ping-pong" mechanism which amplifies these small RNAs [24]. Several studies have identified and characterized viral piRNA (vpiRNA) or piRNA-like small RNAs in mosquitoes or mosquito cells [12,20-23]. Nonetheless, it remains unclear if vpiRNAs exert an antiviral activity.

Both siRNA and piRNA antiviral immunity could be triggered by the direct binding of small RNA on the viral RNA genome. Some studies indicated that the miRNA pathway could presumably participate in antiviral responses [25-31]. The miRNA pathway shares some similarities with the siRNA pathway, but their differences are more significant [9,11,32]; both have nuclear and cytoplasmic phases as the precursor RNAs are produced in the nucleus. The miRNA precursors (pri-miRNAs) originate from independent miRNA genes or mirtrons which are encoded as introns within RNA transcripts. The hairpin-structured pri-miRNAs are processed by the RNase III-type endonuclease Drosha into $\sim 70$ bp hairpins, which are then cleaved into $\sim 20$ bp miRNA duplexes by Dicer-1 after being exported from the nucleus into the cytoplasm by Exportin5 [33-35]. The miRNA duplexes in the cytoplasm are loaded into Ago-1 or Ago-2 proteins in miRNA-induced silencing complexes (miRISCs) according to their different structures [36-38]. Mainly using residues $2-8$ at the $5^{\prime}$ end of mature miRNA (seed region), the miRISC uses the guide strand to find complementary RNA sequences, which leads to RNA degradation (carried out by Ago-2), translational inhibition, or both (mediated by other Ago proteins other than Ago-2) [39,40]. Commonly, animal miRNA binding sites are mainly in the $3^{\prime}$ UTR [41], however miRNA binding sites in the $5^{\prime}$ UTR or coding regions were also reported and are involved in post-transcriptional gene regulation [42-44]. The miRNA antiviral immunity in mosquitoes was shown to facilitate the replication of dengue virus (DENV) or West Nile virus (WNV) in mosquitoes or Drosophila cell lines that are deficient in the biogenesis of some miRNA components [45,46]. In addition, 
the miRNA transcriptomes were also changed in response to chikungunya virus (CHIKV), DENV, and Zika virus (ZIKV) infection in Aedes spp [29,31,47-50].

Mosquito miRNAs are involved in viral replication by regulating host factors or direct miRNA-vRNA interaction. Some miRNAs reported in Aedes spp. mosquitoes can limit viral replication as a consequence of the down-regulation of mosquito genes. A miRNA, miR-2940 in Ae. aegypti and Aedes albopictus could be triggered by virus infection leading to a down-regulation of metalloprotease, which is essential for virus replication. This antiviral miRNA inhibits the replication of CHIKV, DENV, WNV, and even Palm Creek virus (PCV, an insect-specific flavivirus) in Ae. aegypti or Ae. Albopictus [30,48,51,52]. Notably, even though bioinformatics approaches suggested a target site of miR-2940 in the $3^{\prime} \mathrm{UTR}$ of WNV, it has been experimentally demonstrated that this miRNA has no significant effect on viral replication [52]. Another example is aae-miR-2b-3p in Ae. aegypti; aae-miR-2b-3p is up-regulated in response to CHIKV infection. Knocking down an ubiquitin-related modifier (URM) [53] impedes the thiolation of tRNA and consequently, limits CHIKV infection [54].

Surprisingly, only a few studies have shown that mosquito miRNAs interfere with virus replication via complementarity with viral RNA genome in mosquitoes. Two binding sites of aal-miR-252 and aal-miR-281 (from Ae. albopictus) were found in the genomic RNA of DENV at the envelope protein and $5^{\prime}$ UTR regions, respectively $[55,56]$. However, aal-miR-252 can limit the viral replication, whereas aal-miR-281 facilitates DENV replication via a direct interaction at the $5^{\prime}$ UTR. Besides, expressing synthetic miRNAs complementary to arboviral RNA genome was shown to reduce the transmission of CHIKV, DENV, and ZIKV [57,58], thus indirectly supporting the hypothesis that cellular miRNA can target viral nucleic acids and replication.

There is still a remarkable lack of information about the direct miRNA-vRNA interaction in mosquitoes. However, miRNAs are more easily identified by next-generation sequencing (NGS) techniques and are now available in databases while improved bioinformatics tools have been developed. To predict potential mosquito miRNA binding sites in the viral RNA, we compared published small RNA sequencing data from Ae. aegypti to virus sequence data of three major arboviruses, e.g., CHIKV, DENV (serotypes 1-4), and ZIKV. We predicted and analyzed the potential target sites on each virus genome to reveal practicable miRNA-vRNA interactions by combining thermodynamics and miRNA expression profiles. This approach can underpin future studies on the role of miRNAs in regulating arbovirus replication in mosquito cells. Notably, the biological meaning of the prediction results was only important after experimental validations.

\section{Methods}

\subsection{Identification Strategies for miRNA and vRNA Interactions}

Key human pathogenic arboviruses (flaviviruses, DENV1-4, ZIKV, and the alphavirus, CHIKV) were chosen for analyzing the relationship between miRNAs and viral genomes (vRNA). The genome sequences for each virus were collected from the virus database Virus Pathogen Resource (ViPR, www.ViPRbrc.org) [59,60], while the miRNA sequences of Ae. aegypti were retrieved from the miRNA database, miRBase, and published results of small RNA sequencing [61]. Predictions of miRNA-vRNA interactions were carried out mainly using miRanda software [62] and in coordination with TargetSpy [63] via the online tool sRNAtoolbox [64] with default settings (http://bioinfo5.ugr.es/ srnatoolbox). The consensus binding sites predicted by both software were extracted by BEDtools (version 2.25.0) [65]. Only the prediction sites shared by the two prediction algorithms were chosen for a further case study and evaluation of the affinity of each miRNA-vRNA complex. In addition, the structures of these complexes were predicted using the tool RNAhybrid [66] via BiBiServ2 (https://bibiserv2.cebitec.uni-bielefeld.de). Total of 261, 1671, 1244, 884, 164, and 157 complete viral genomes of CHIKV, DENV1-4, and ZIKV, respectively, were retrieved from ViPR as data input for miRNA-vRNA prediction; the viruses from each genotype were chosen for further analysis, as they showed the highest number of potential miRNA binding sites. 


\subsection{Flowchart Validation}

Experiment data of a luciferase reporter of Ae. aegypti miRNA-mRNA interactions published by Zhang, et al. [67] were applied to validate the workflow for predicting miRNA binding sites we have adopted in this study. AAEL013070, AAEL006834, AAEL000577, and AAEL010015 of Ae. aegypti were shown to be regulated by aae-miR-11-3p (AAEL013070), aae-miR-275-3p (AAEL006834 and AAEL000577), and aae-miR-286b-3p (AAEL010015) in the 3'UTR [67]. Among the four most significant miRNA-mediated reductions validated by Zhang, Aksoy, Girke, Raikhel and Karginov [67], three of them could be correctly identified with our workflow. These transcripts and the miRNA database of Ae. aegypti were used as input data. Using the default setting, the 3'UTR binding sites for aae-miR-11-3p in AAEL013070 $(-13.04 \mathrm{kcal} / \mathrm{mol})$ and aae-miR-275-3p for AAEL006834 $(-18.7 \mathrm{kcal} / \mathrm{mol})$ and AAEL000577 $(-15.89 \mathrm{kcal} / \mathrm{mol})$, were commonly predicted by both miRanda and TargetSpy. Even though no consensus binding site at the $3^{\prime} \mathrm{UTR}$ for aae-miR-286b-3p could be found in AAEL000577 with both algorithms, a potential binding site for aae-miR-286b-3p at the $3^{\prime}$ UTR could be detected at two distinct positions by miRanda and TargetSpy (http://bioinfo5.ugr.es/srnatoolbox).

\section{Results}

\subsection{Several Potential miRNA Binding Sites Were Predicted in Viral RNA Genomes}

With our prediction flowchart, a total of 674 miRNA-vRNA interactions were predicted consensually by both algorithms for each virus (Figure 1). Among them, 93 potential binding sites could be found in CHIKV genome, 151, 130, 123, and 98 potential binding sites found in the genomes of DENV1-4, respectively, and 79 potential binding sites in the ZIKV genome.

\section{2. miRNA Binding Sites in the CHIKV Genome}

CHIKV belongs to the family of Togaviridae and the genus Alphavirus, with three genotypes circulating worldwide: East/Central/South African (ECSA), West African (WA), and Asian. One additional CHIKV lineage, Indian Ocean lineage (IOL), emerged in 2004-5 from the ECSA phylogroup and has spread throughout many tropical regions [68]. The IOL lineage predominates in regions where the vector Ae. albopictus is present/dominant, in part due to the selection of an $A e$. albopictus-adaptive substitution in the CHIKV E1 envelope glycoprotein (E1-A226V). This substitution confers efficient infection and dissemination in Ae. albopictus for IOL of CHIKV [69,70]. The Asian and IOL/ECSA genotypes were responsible for the most recent outbreaks [71].

Four CHIKV genotypes were selected for this study: Asian (EU703762), ECSA (HM045811), IOL (AM258992), and WA (HM045816). Two analytical tools, miRanda and TargetSpy, were used to identify a total of 20, 25, 26, and 22 miRNA binding sites that were commonly found for CHIKV of different genotypes and lineages (Asian, ECSA, IOL, and WA) (Figure 2a).

When comparing the binding sites previously identified among all four genotypes, the highest number of shared binding sites was between ECSA and IOL genotypes $(n=18)$, whereas WA and Asian genotypes were relatively independent to each other with no common binding sites (Figure 2a). Among them, six miRNA binding sites were common among Asian, ECSA, and IOL genotypes, which could be targeted by aae-miR-263a-5p, aae-miR-279-3p, aae-miR-305-5p, aae-miR-34-3p, and aae-miR-996-3p (Supplementary Table S1). And among three potential miRNA binding sites that are commonly found among WA, ECSA, and IOL genotypes, two might potentially be targeted by aae-miR-285-5p and aae-miR-989-3p in the E1 and Capsid coding regions, respectively. The other miRNA binding site shared among WA, ECSA, and IOL genotypes may potentially be targeted by aae-miR-iab-4-5p in the $3^{\prime}$ UTR. Notably, this miRNA might have an additional binding site on the $5^{\prime}$ UTR of ECSA and IOL genotypes. Any activity of this miRNA might be increased by multiple binding sites on the $5^{\prime}$ - and $3^{\prime}$ UTR of CHIKV involved in initiating viral RNA replication [72]. In addition, as the synthesis of subgenomic RNA from minus strand of RNA genome is critical for CHIKV replication, the minus strand genomic RNA of CHIKV was also analyzed via the flowchart. The result showed only one 
potential binding site that could be consensually found in the minus strand of CHIKV RNA genome; for aae-miR-282-5p (Supplementary Figure), the predicted binding sites were shown in Supplementary Table S2.

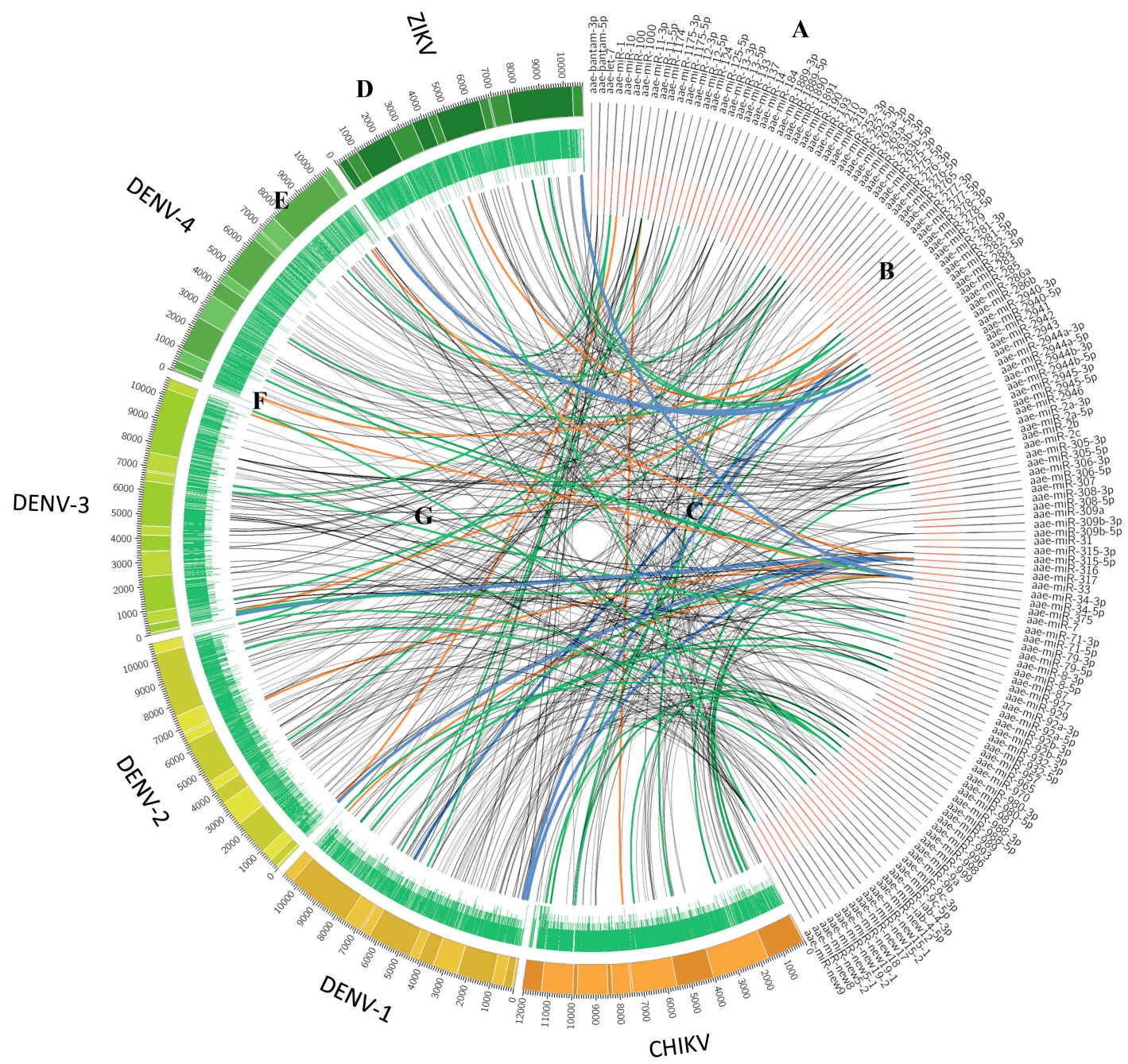

Figure 1. The interactome of Ae. aegypti micro RNAs (miRNAs) with chikungunya virus (CHIKV), Dengue virus (DENV), and Zika virus (ZIKV) genomes as predicted by miRanda and TargetSpy. (A) miRNAs of Ae aegypti; (B) miRNA and its seed regions (seed regions in red); (C), links between miRNAs and potential binding regions on the viruses; (D) genomes of arboviruses; (E) dark and light areas represent the protein coding regions in each virus; (F) conservation scores of virus among all the genotypes; green links, the miRNA binding site shared among most of the genotypes discussed in this study; orange links, the miRNA-viralRNA (vRNA) with low energy; blue links, the miRNA-vRNA with low energy shared among most arboviruses; black links, remaining miRNA-vRNA interactions.

\section{3. miRNA Binding Sites in DENV Genomes}

DENV has evolved independently into four serotypes from distinct sylvatic progenitors and then into several genotypes [73]. They only share $60-75 \%$ sequence similarity and need to be analyzed separately to find potential miRNA-vRNA interactions [74]. Several conserved miRNA binding sites could be found in each serotype which might participate in viral regulation, as outlined below.

\section{4. $D E N V-1$}

Five genotypes of DENV-1 were selected for analysis: genotype I (AF298808), genotype II (JQ922547), genotype III (DQ285562), genotype IV (EF025110), and genotype V (JX669462). A total of 
$28,30,34,33$, and 26 potential binding sites were found in genotypes I, II, III, IV, and V, respectively (Figure $2 b$ ). Among them, only two potential miRNA binding sites were common to all five genotypes of DENV-1, which could be targeted respectively by aae-miR-1-3p and aae-miR-282-5p on the capsid and NS3 protein coding regions (Supplementary Table S1). Furthermore, six potential miRNA binding sites were commonly found in four of the five genotypes (Supplementary Table S1). The NS5 region of genotypes I, II, III, and V could potentially be targeted by aae-miR-316-5p, aae-miR-92a-3p, and aae-miR-92b-3p. In addition, the miRNA aae-miR-316-5p might have a further potential binding site within the capsid region (genotypes I, III, IV, and V), which may increase the probability of miRNA-vRNA interactions. The only miRNA that was found with a common binding site in genotypes I, II, IV, and V within NS4B is aae-miR-11-5p (Supplementary Table S1). Two potential miRNA binding sites for aae-miR-263a-3p and aae-miR-998-3p were found conserved on the 3'UTR of genotypes I, III, and V (Supplementary Table S1).

\section{5. $D E N V-2$}

Five genotypes of DENV-2 were selected for our analysis: Asian I (DQ181799), Asian II (AJ968413), Asian American (DQ181801), American (AY702040), and Cosmopolitan (AB189122). We found a total of 28, 31, 21, 22, and 28 potential binding sites on each genotype respectively (Figure 2c). Among them, binding sites for aae-miR-316-5p, and aae-miR-9c-5p were common to all five genotypes (Supplementary Table S1).

Three other miRNA binding sites were shared between at least four genotypes. Two binding sites were common between Asian I, Asian II, Asian American, and Cosmopolitan genotypes: aae-miR-281-3p within NS2B, and aae-miR-998-3p within the $3^{\prime}$ UTR region of DENV-2. Another miRNA, aae-miR-315-5p, was also predicted to target the NS5 region of all DENV-2 genotypes except the Asian I genotype. The only miRNA predicted to target Asian I, Asian American, American, and Cosmopolitan genotypes of DENV-2 is aae-miR-263a-3p, which has a potential binding site on the $3^{\prime}$ UTR. In addition, the same miRNA binding site within the 3'UTR of DENV-2 was also found within the same region of DENV-1.

\section{6. $D E N V-3$}

Four genotypes of DENV-3 were selected for our analysis: genotype I (AY744677), genotype II (AY676352), genotype III (AY099336), and genotype V (AF317645). Again, 25, 38, 41, and 29 potential binding sites were identified in genotypes I, II, III, and V, respectively (Figure 2d). Five miRNA binding sites were predicted to be conserved in all four genotypes. Among these, aae-miR-124-3p, aae-miR-281-3p, and aae-miR-998-3p were predicted to target the NS4A, prM, and 3'UTR regions, respectively. Also, the capsid region was predicted to have two target sites for aae-miR-316-5p (except genotype I) and one target site for aae-miR-79-3p.

\section{7. $D E N V-4$}

Three genotypes of DENV-4 were selected for our analysis: genotype I (AY618992), genotype II (FJ639737), and genotype III (AY618988). We identified 32, 37, and 21 potential miRNA binding sites for genotypes I, II, and III of DENV-4, respectively (Figure 2e). Among them, three potential miRNA binding sites were common to all three genotypes and targeted by aae-miR-1-3p, aae-miR-219-5p, and aae-miR-281-3p in NS5 and NS2A regions (Supplementary Table S1).

\section{8. miRNA Targeting the ZIKV Genome}

ZIKV was first isolated from Aedes africanus mosquitoes in 1948 [75] although serological evidence has shown a broader geographic distribution of human infections including North/East Africa and South/Southeast Asia [76-83]. Since the first human case reported in Nigeria in 1952 [81], only 13 cases of mild, febrile illness were reported until the outbreak in the State of Yap (Federated States of Micronesia) in 2007 [84-87], where more than $70 \%$ of the population were infected. [88] Later, cases 
of ZIKV related Guillain-Barré syndrome were notified during the outbreak in French Polynesia in 2013-2014. [89,90] The first ZIKV case reported in America was in 2015 in Bahia (Brazil) [91,92]. ZIKV caused a total of 51,473 suspected cases and more than 4300 cases of microcephaly in Brazil by March $2016[93,94]$, and the virus spread to at least 33 countries or areas in the Americas [93,95]. Related to DENV, ZIKV belongs to the Flaviviridae family and the genus Flavivirus. The three distinct genotypes East Africa (EA), West Africa (WA), and Asian were likely to be originated in East Africa [96,97]. ZIKV has a conserved genome with less than $12 \%$ divergence at a nucleotide level among all virus strains, and with $99 \%$ nucleotide similarity for strains from the Americas [98]. Thus, the interactions between mosquito miRNA and viral RNA could be more relevant than between highly divergent viruses and might provide a new insight for evaluating the antiviral immunity of mosquitoes against newly emergent viruses. Three genotypes of ZIKV were selected for analysis: EA (KF268949), WA (JU955592), and Asian (KU365778). According to our results, 30, 22, and 27 potential binding sites were found in EA, WA, and Asian genotypes respectively (Figure 2f).
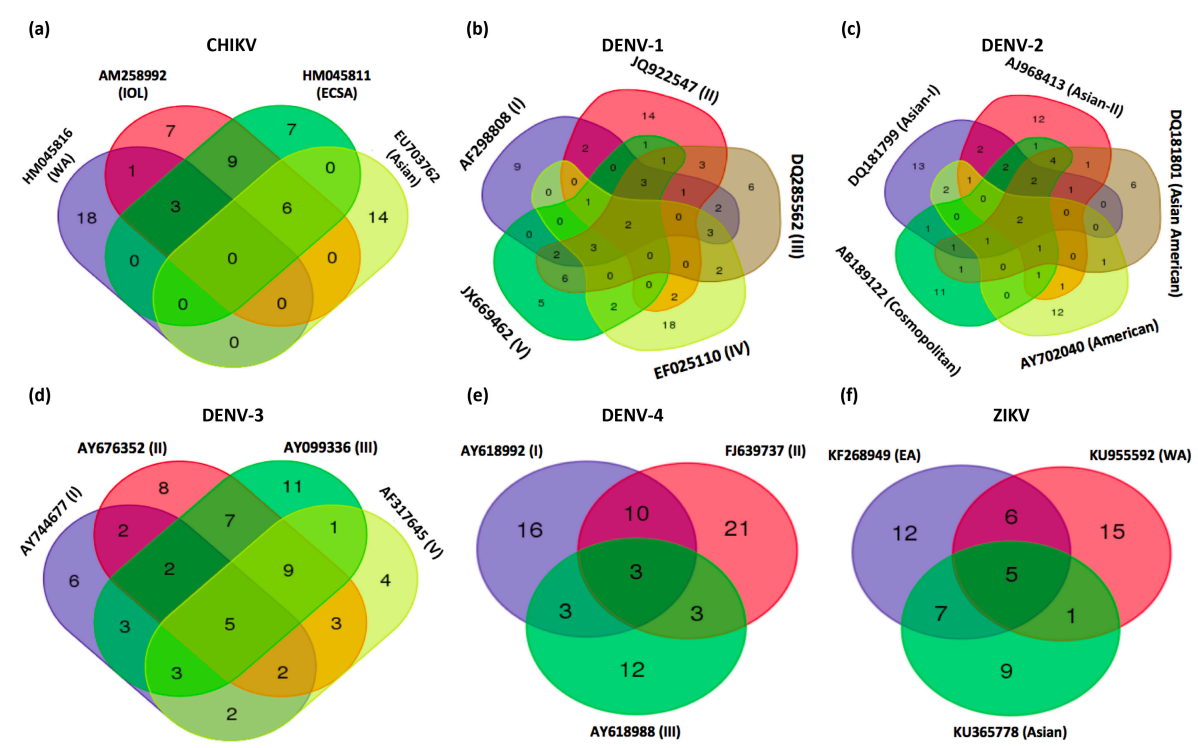

Figure 2. Venn-diagram presentation of common prediction binding sites on each genotype/lineage of CHIKV, DENV1-4, and ZIKV for Ae. aegypti miRNAs (a-f). miRNAs that were sorted by the conservation of target sites that might show a more general miRNA-vRNA interaction. (a) AM258992, Indian Ocean Lineage, IOL; HM045816, West African, WA; EU703762, Asian; HM045811, East/Central/South African, ECSA; (b) AF298808, genotype I; JQ922547, genotype II; DQ285562, genotype III; EF025110, genotype IV; JX669462, genotype V; (c) DQ181799, Asian-I; AJ968413, Asian-II; DQ181801, Asian American; AY702040, American; AB189122, Cosmopolitan; (d) AY744677, genotype I; AY676352, genotype II; AY099336, genotype III; AF317645, genotype V; (e) AY618992, genotype I; FJ639737, genotype II; AY618988, genotype III; (f) KF268949, East African, EA; KU955592, West African, WA; KU365778, Asian. The numbers with an asterisk represent the miRNA binding sites; the most common in each virus group were listed in Supplementary Table S1.

Five potential miRNA binding sites within the $5^{\prime} \mathrm{UTR}, \mathrm{NS} 2 \mathrm{~A}, \mathrm{NS5}$, and $3^{\prime} \mathrm{UTR}$ were common among all three genotypes (Supplementary Table S1): aae-miR-286a-3p, aae-miR-286b-3p, aae-miR-34-3p, and aae-miR-new8. Among them, aae-miR-286a-3p, aae-miR-286b-3p, and aae-miR-34-3p were predicted to target the $5^{\prime}$ or 3'UTR region of ZIKV. Moreover, aae-miR-286a-3p has an additional potential binding site on the NS5 region.

\subsection{Selection of miRNAs and Thermodynamic Analysis}

Sequence complementary is an important but not the only factor that modulates the miRNA-vRNA interactions. The thermodynamic between miRNA and vRNA is another crucial factor that has 
an effect on the formation of miRNA-vRNA complex. Several miRNAs were predicted to have a low minimum free energy (MFE), indicating a relatively high affinity to form miRNA-vRNA complexes. To assess the potential interaction between miRNAs and the binding sites that are not highly conserved among genotypes but have relatively high potential to form miRNA-vRNA complexes in Ae. aegypti, we set up an MFE cut-off with $-20 \mathrm{kcal} / \mathrm{mol}$ for evaluating miRNA-vRNA affinity $[49,99]$. According to this prediction data, we identified eight miRNAs—namely aae-miR-10-5p, aae-miR-11-5p, aar-miR-278-3p, aae-miR-282-5p, aae-miR-286a-3p, aae-miR-286b-3p, aae-miR-316-5p, and aae-miR-34-3p. These miRNAs could potentially target more than one genotype/lineage of each virus species with an MFE below $-20 \mathrm{kcal} / \mathrm{mol}$ for each miRNA-vRNA complex (Figure 3). The possible structures formed by miRNA-vRNA interactions were predicted using RNAhybrid (Figure 4).

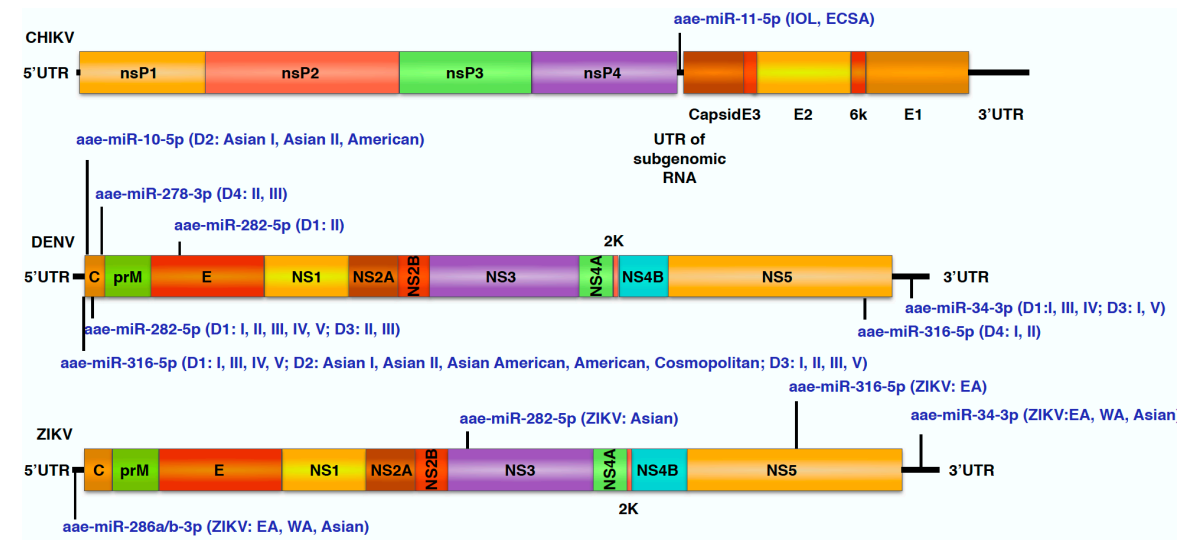

$1 \mathrm{~kb}$

Figure 3. Predicted miRNA-vRNA interactions sorted with minimum free energy (MFE) value and compromised sequence conservation in each genotype/lineage in this study. The scheme shows the most likely miRNA-vRNA interactions predicted in this study. Each miRNA could target multiple viruses, has a relatively low MFE (around $-20 \mathrm{kcal} / \mathrm{mol}$ ), and is predicted to target more than one genotype of each virus.

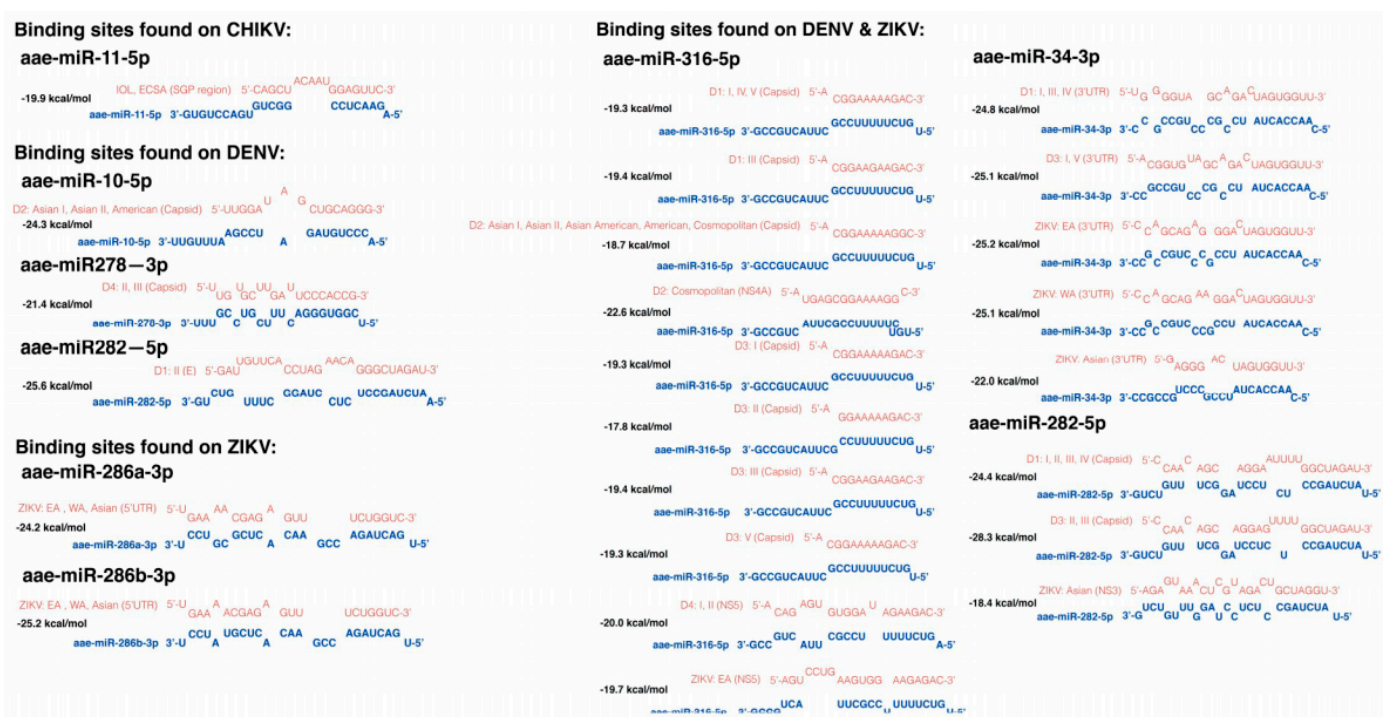

Figure 4. Possible structures of each low MFE miRNA-vRNA interaction predicted by RNAhybrid. The structures of seven low MFE miRNAs of Ae. aegypti potentially interact with CHIKV, DENV, and ZIKV. Among them, the possible binding sites for aae-miR-316-5p and aae-34-3p, and aae-miR-282-5p could be commonly found on both DENV and ZIKV. Sequence in red: the potential targets in RNA genome of each virus; sequence in blue: cellular miRNAs of Ae. aegypti. 


\section{Discussion}

As poikilotherms, the body temperature of mosquitoes is influenced by ambient temperature, resulting in a different miRNA thermodynamic stability profile in insects than vertebrates [100]. Using adequate algorithms that have high prediction accuracy in insects is then important for predicting the potential miRNA-vRNA interactions. Here, two algorithms, miRanda and TargetSpy, were chosen for analyzing the mosquito potential miRNA-vRNA interactions. Several potential mosquito miRNA-vRNA interactions could be consensually predicted by both algorithms. miRanda and TargetSpy are two powerful algorithms for predicting the miRNA potential binding sites on target sequences in insects. miRanda is one of the most extensively used miRNA target prediction tools and was applied originally for identifying miRNA binding sites in Drosophila and mosquitoes. The miRanda algorithm works in three phases. Firstly, the complementarity matches between the input miRNAs and RNA sequences were identified based on dynamic programming algorithm alignment. Secondly, a thermodynamic calculation was made to rule out the matches with an MFE value above the threshold. Finally, the remaining results were filtered by checking the sequence conservation with Drosophila melanogaster, Drosophila pseudoobscura, and Anopheles gambiae. In addition, miRanda can also weigh the matches between the $2^{\text {nd }}$ to the $8^{\text {th }}$ nucleotide from the $5^{\prime}$ arm of miRNA (seed-region), to evaluate the potential for that miRNA-vRNA complex to form [62]. For a more stringent selection, the same database was filtered with the other algorithm, TargetSpy. Unlike miRanda, TargetSpy is an algorithm based on machine learning and automatic feature selection with a broad spectrum of compositional, structural, and base pairing of each miRNA to the targeted sequence [63]. TargetSpy is able to predict species-specific targets, as the miRNA-vRNA interactions are not extensively studied. Besides, even though trained on mouse data, TargetSpy is an algorithm which shows the highest accuracy among several other algorithms on experimentally proven datasets (including insects) [63]. Using a combination of miRanda and TargetSpy, we obtained consensus results which should be more robust for detecting miRNAs that are interacting with viral genomes. Moreover, a more reliable miRNA-vRNA interaction was examined by comparing these results with the structure information predicted by RNAhybrid.

Despite the amount of false positive miRNA-target interactions predicted by several algorithms due to the nature of miRNA target recognition [101], other factors like MFE that affect miRNA-target interaction were applied for results sorting. The lower the MFE, the higher the potential to form the miRNA-target complex [102,103]; in order to narrow down the possible miRNA candidates, a relatively stringent cut-off, $-20 \mathrm{kcal} / \mathrm{mol}$, was applied in this study [62]. Even though MFE is an important factor affecting miRNA-vRNA complex formation, it does not certify that the interaction will lead to functional changes.

In this study, we found eight miRNA binding sites that both have low MFE and are also relatively conserved in each genotype/lineage. In theory, these miRNAs have a higher chance to form a miRNA-vRNA complex with more than one genotype/lineage of virus, and thus might subsequently be involved in virus replication. Moreover, according to the predicted binding sites, depending on the binding regions, some of them might have an even higher chance to participate in virus replication; the predicted binding sites for aae-mir-11-5p, aae-miR-286a/b-3p, aae-miR-316-5p, and aae-miR-34-3p are located in important viral regulatory regions such as the $3^{\prime} \mathrm{UTR}, 5^{\prime} \mathrm{UTR}$, or the subgenomic RNA untranslated region of the three tested viruses. Aae-mir-286a/b-3p was predicted to target all genotypes of ZIKV at the 5'UTR; although not highly expressed, this miRNA is an ovary specific miRNA and could be deposited into embryos [104]. It might be worth exploring the potential relationship between this miRNA and the vertical transmission of ZIKV. Except for DENV-4, most DENV genotypes were predicted to have a binding site for aae-miR-316-5p at the $5^{\prime}$ UTR region; aae-miR-316-5p being a miRNA that could be detectable in the fat body and slightly up-regulated in midguts $24 \mathrm{~h}$ after receiving a blood meal $[67,105]$. However, the effectiveness of aae-miR-316-5p might be reduced due to the relatively low expression level [105]. Conserved aae-miR-34-3p binding sites could be found in the 3'UTR of ZIKV, DENV-1, and DENV-3; this miRNA was reported to be up-regulated in response to 
CHIKV and Wolbachia infection [53,106]. Finally, the only miRNA that has low MFE and is relatively conserved among lineages of CHIKV is aee-miR-11-5p, which was predicted to target the end of the subgenomic untranslated RNA region, which also covers the start codon of the viral structural polyprotein of CHIKV. Therefore, the expression of CHIKV structural proteins might be influenced by the formation of a miRNA-vRNA complex at the end of subgenomic RNA untranslated regions, which might antagonize the binding region with host translational factors. In addition, aae-miR-11-5p is also one of the most abundantly expressed miRNAs in Ae. Aegypti [104], which could increase the chance of complex formation. Notably, the replication of the three arboviruses relies on the duplication of viral polyproteins. Thus, a single effective miRNA-vRNA interaction in the viral genome is sufficient to regulate viral replication. In mammals, more evidence is available on the role of virus replication regulated by direct miRNA-vRNA interactions [107-115], whether facilitation or reduction.

The critical roles of cellular miRNAs in host viral immunity have received more attention elsewhere with mammalian host miRNA-vRNA interactions $[107,108]$. In humans, the interaction between the liver specific miR-122 and the 5'UTR of Hepatitis C virus (HCV) stabilizes the viral RNA facilitating viral replication [116,117]. On the contrary, the replication of the arbovirus Eastern equine encephalitis virus (EEEV) could be reduced by the human hematopoietic cell specific miR-142-3p that has four binding sites in the 3'UTR [109]. In contrast, there is still a lack of information on the miRNA targetome for Ae. aegypti. However, few studies have demonstrated that the replication of some genotypes of DENV-2 could be affected by direct miRNA-vRNA interaction in Ae. Albopictus [55,56], and CHIKV, DENV-3, and ZIKV transmission could be reduced in synthetic antiviral miRNA expressing genetically modified Ae. Aegypti $[57,58]$, suggesting the cellular miRNA can target viral RNA, and such interactions could potentially affect viral RNA replication.

In this study, we used the consensus results from two adequate algorithms to predict the possible interactions between Ae. aegypti cellular miRNAs and three arboviruses. We further sorted the results according to the sequence conservation among genotypes or the miRNA-vRNA interactions with low MFE and provided several candidates for further investigation. Even though we could merely provide a list of candidates, it remains necessary to evaluate the role of each potential miRNA on virus replication, and the subsequent reduction or facilitation of virus replication has to be demonstrated experimentally. Inhibitor studies should shed light on individual miRNA-vRNA interactions. However, miRNA-vRNA interactions can also be proven by techniques such as Argonaute-crosslinking immunoprecipitation (AGO-CLIP), and mutagenic analysis of virus genomes is possible for many of the arboviruses investigated here.

Supplementary Materials: The following are available online at http://www.mdpi.com/1999-4915/11/6/540/s1, Figure S1: Venn-diagram presentation of common prediction binding sites on CHIKV negative sense RNA genome of each genotype/lineage., Table S1: Most common miRNA sites targeting each genotype of CHIKV, DENV1-4, and ZIKV, Table S2: Most common miRNA sites targeting each genotype of negative-sense CHIKV RNA genome.

Author Contributions: P.-S.Y. and A.-B.F. contributed to conceiving, performing the analysis and writing the paper. C.-H.C., V.S., and A.K. helped in interpreting the data. A.K. helped editing the paper. All authors reviewed the paper.

Funding: This study was partly supported by the European Union's Horizon 2020 Research and innovation program under "ZIKALLIANCE" Grant Agreement n ${ }^{\circ} 734548$ ) (ABF, AK), the French Government's Investissement d'Avenir program, Laboratoire d'Excellence "Integrative Biology of Emerging Infectious Diseases, IBEID" (grant $\mathrm{n}^{\circ}$ ANR-10-LABX-62-IBEID) (ABF), the National Health Research Institutes (NHRI-PP-108-0324-01-17-07) (CHC), and the UK Medical Research Council [MC_UU_12014] (AK and VS). PSY was supported by the Pasteur-Paris University (PPU) program.

Acknowledgments: We thank Wei OUYANG, Catherine DAUGA, Adrien PAIN, and Michele MARCONCINI for advice. We are grateful to Claire DONALD for editing this manuscript.

Conflicts of Interest: The authors declare no competing interests. 


\section{References}

1. Powers, A.M.; Waterman, S.H. A decade of arboviral activity-Lessons learned from the trenches. PLoS Negl. Trop. Dis. 2017, 11, e0005421. [CrossRef] [PubMed]

2. Weaver, S.C.; Reisen, W.K. Present and future arboviral threats. Antivir. Res. 2010, 85, 328-345. [CrossRef] [PubMed]

3. Jones, K.E.; Patel, N.G.; Levy, M.A.; Storeygard, A.; Balk, D.; Gittleman, J.L.; Daszak, P. Global trends in emerging infectious diseases. Nature 2008, 451, 990-993. [CrossRef] [PubMed]

4. Grubaugh, N.D.; Weger-Lucarelli, J.; Murrieta, R.A.; Fauver, J.R.; Garcia-Luna, S.M.; Prasad, A.N.; Black, W.C., IV; Ebel, G.D. Genetic Drift during Systemic Arbovirus Infection of Mosquito Vectors Leads to Decreased Relative Fitness during Host Switching. Cell Host Microbe 2016, 19, 481-492. [CrossRef] [PubMed]

5. Kramer, L.D.; Ebel, G.D. Dynamics of flavivirus infection in mosquitoes. Adv. Virus Res. 2003, 60, $187-232$. [PubMed]

6. Franz, A.W.; Kantor, A.M.; Passarelli, A.L.; Clem, R.J. Tissue Barriers to Arbovirus Infection in Mosquitoes. Viruses 2015, 7, 3741-3767. [CrossRef] [PubMed]

7. van Mierlo, J.T.; van Cleef, K.W.; van Rij, R.P. Defense and counterdefense in the RNAi-based antiviral immune system in insects. Methods Mol. Biol. 2011, 721, 3-22. [CrossRef] [PubMed]

8. Merkling, S.H.; van Rij, R.P. Beyond RNAi: Antiviral defense strategies in Drosophila and mosquito. J. Insect Physiol. 2013, 59, 159-170. [CrossRef] [PubMed]

9. Blair, C.D.; Olson, K.E. The role of RNA interference (RNAi) in arbovirus-vector interactions. Viruses 2015, 7, 820-843. [CrossRef]

10. Olson, K.E.; Blair, C.D. Arbovirus-mosquito interactions: RNAi pathway. Curr. Opin. Virol. 2015, 15, 119-126. [CrossRef]

11. Donald, C.L.; Kohl, A.; Schnettler, E. New Insights into Control of Arbovirus Replication and Spread by Insect RNA Interference Pathways. Insects 2012, 3, 511-531. [CrossRef] [PubMed]

12. Miesen, P.; Joosten, J.; Van Rij, R.P. PIWIs Go Viral: Arbovirus-Derived piRNAs in Vector Mosquitoes. PLoS Pathog. 2016, 12, e1006017. [CrossRef] [PubMed]

13. Fragkoudis, R.; Attarzadeh-Yazdi, G.; Nash, A.A.; Fazakerley, J.K.; Kohl, A. Advances in dissecting mosquito innate immune responses to arbovirus infection. J. Gen. Virol. 2009, 90, 2061-2072. [CrossRef] [PubMed]

14. Keene, K.M.; Foy, B.D.; Sanchez-Vargas, I.; Beaty, B.J.; Blair, C.D.; Olson, K.E. RNA interference acts as a natural antiviral response to O'nyong-nyong virus (Alphavirus; Togaviridae) infection of Anopheles gambiae. Proc. Natl. Acad. Sci. USA 2004, 101, 17240-17245. [CrossRef] [PubMed]

15. Campbell, C.L.; Black, W.C.; Hess, A.M.; Foy, B.D. Comparative genomics of small RNA regulatory pathway components in vector mosquitoes. BMC Genom. 2008, 9, 425. [CrossRef]

16. Sanchez-Vargas, I.; Scott, J.C.; Poole-Smith, B.K.; Franz, A.W.E.; Barbosa-Solomieu, V.; Wilusz, J.; Olson, K.E.; Blair, C.D. Dengue Virus Type 2 Infections of Aedes aegypti Are Modulated by the Mosquito's RNA Interference Pathway. PLoS Pathog. 2009, 5, e1000299. [CrossRef] [PubMed]

17. Carissimo, G.; Pondeville, E.; McFarlane, M.; Dietrich, I.; Mitri, C.; Bischoff, E.; Antoniewski, C.; Bourgouin, C.; Failloux, A.B.; Kohl, A.; et al. Antiviral immunity of Anopheles gambiae is highly compartmentalized, with distinct roles for RNA interference and gut microbiota. Proc. Natl. Acad. Sci. USA 2015, 112, E176-E185. [CrossRef]

18. Dietrich, I.; Shi, X.; McFarlane, M.; Watson, M.; Blomström, A.-L.; Skelton, J.K.; Kohl, A.; Elliott, R.M.; Schnettler, E. The Antiviral RNAi Response in Vector and Non-vector Cells against Orthobunyaviruses. PLoS Negl. Trop. Dis. 2017, 11, e0005272. [CrossRef]

19. Miesen, P.; Ivens, A.; Buck, A.H.; Van Rij, R.P. Small RNA Profiling in Dengue Virus 2-Infected Aedes Mosquito Cells Reveals Viral piRNAs and Novel Host miRNAs. PLoS Negl. Trop. Dis. 2016, 10, e0004452. [CrossRef]

20. Brackney, D.E.; Scott, J.C.; Sagawa, F.; Woodward, J.E.; Miller, N.A.; Schilkey, F.D.; Mudge, J.; Wilusz, J.; Olson, K.E.; Blair, C.D.; et al. C6/36 Aedes albopictus Cells Have a Dysfunctional Antiviral RNA Interference Response. PLoS Negl. Trop. Dis. 2010, 4. [CrossRef]

21. Schnettler, E.; Donald, C.L.; Human, S.; Watson, M.; Siu, R.W.C.; McFarlane, M.; Fazakerley, J.K.; Kohl, A.; Fragkoudis, R. Knockdown of piRNA pathway proteins results in enhanced Semliki Forest virus production in mosquito cells. J. Gen. Virol. 2013, 94, 1680-1689. [CrossRef] [PubMed] 
22. Morazzani, E.M.; Wiley, M.R.; Murreddu, M.G.; Adelman, Z.N.; Myles, K.M. Production of Virus-Derived Ping-Pong-Dependent piRNA-like Small RNAs in the Mosquito Soma. PLoS Pathog. 2012, 8, e1002470. [CrossRef] [PubMed]

23. Hess, A.M.; Prasad, A.N.; Ptitsyn, A.; Ebel, G.D.; E Olson, K.; Barbacioru, C.; Monighetti, C.; Campbell, C.L. Small RNA profiling of Dengue virus-mosquito interactions implicates the PIWI RNA pathway in anti-viral defense. BMC Microbiol. 2011, 11, 45. [CrossRef] [PubMed]

24. Brennecke, J.; Aravin, A.A.; Stark, A.; Dus, M.; Kellis, M.; Sachidanandam, R.; Hannon, G.J. Discrete Small RNA-Generating Loci as Master Regulators of Transposon Activity in Drosophila. Cell 2007, 128, 1089-1103. [CrossRef] [PubMed]

25. Etebari, K.; Osei-Amo, S.; Blomberg, S.P.; Asgari, S. Dengue virus infection alters post-transcriptional modification of microRNAs in the mosquito vector Aedes aegypti. Sci. Rep. 2015, 5, 15968. [CrossRef]

26. Etebari, K.; Hegde, S.; Saldaña, M.A.; Widen, S.G.; Wood, T.G.; Asgari, S.; Hughes, G.L. Global Transcriptome Analysis of Aedes aegypti Mosquitoes in Response to Zika Virus Infection. mSphere 2017, 2, e00456-17. [CrossRef]

27. Naqvi, A.R.; Shango, J.; Seal, A.; Shukla, D.; Nares, S. Viral miRNAs Alter Host Cell miRNA Profiles and Modulate Innate Immune Responses. Front. Immunol. 2018, 9, 433. [CrossRef]

28. Liu, Y.; Zhou, Y.; Wu, J.; Zheng, P.; Li, Y.; Zheng, X.; Puthiyakunnon, S.; Tu, Z.; Chen, X.-G. The expression profile of Aedes albopictus miRNAs is altered by dengue virus serotype-2 infection. Cell Biosci. 2015, 5, 16. [CrossRef]

29. Saldana, M.A.; Etebari, K.; Hart, C.E.; Widen, S.G.; Wood, T.G.; Thangamani, S.; Asgari, S.; Hughes, G.L. Zika virus alters the microRNA expression profile and elicits an RNAi response in Aedes aegypti mosquitoes. PLoS Negl. Trop. Dis. 2017, 11, e0005760. [CrossRef]

30. Lee, M.; Hall-Mendelin, S.; Hurk, A.F.V.D.; Hobson-Peters, J.; Vatipally, S.; Schnettler, E.; Hall, R.; Etebari, K.; Asgari, S. Understanding the role of microRNAs in the interaction of Aedes aegypti mosquitoes with an insect-specific flavivirus. J. Gen. Virol. 2017, 98, 1892-1903. [CrossRef]

31. Campbell, C.L.; Harrison, T.; Hess, A.M.; Ebel, G.D. MicroRNA levels are modulated in Aedes aegypti after exposure to Dengue-2. Insect Mol. Biol. 2014, 23, 132-139. [CrossRef] [PubMed]

32. Blair, C.D. Mosquito RNAi is the major innate immune pathway controlling arbovirus infection and transmission. Futur. Microbiol. 2011, 6, 265-277. [CrossRef] [PubMed]

33. Yi, R.; Qin, Y.; Macara, I.G.; Cullen, B.R. Exportin-5 mediates the nuclear export of pre-microRNAs and short hairpin RNAs. Genome Res. 2003, 17, 3011-3016. [CrossRef] [PubMed]

34. Kim, V.N.; Han, J.; Siomi, M.C. Biogenesis of small RNAs in animals. Nat. Rev. Mol. Cell Boil. 2009, 10, 126-139. [CrossRef] [PubMed]

35. Ha, M.; Kim, V.N. Regulation of microRNA biogenesis. Nat. Rev. Mol. Cell Boil. 2014, 15, 509-524. [CrossRef] [PubMed]

36. Ghildiyal, M.; Xu, J.; Seitz, H.; Weng, Z.; Zamore, P.D. Sorting of Drosophila small silencing RNAs partitions microRNA* strands into the RNA interference pathway. RNA 2010, 16, 43-56. [CrossRef] [PubMed]

37. Förstemann, K.; Horwich, M.D.; Wee, L.; Tomari, Y.; Zamore, P.D. Drosophila microRNAs Are Sorted into Functionally Distinct Argonaute Complexes after Production by Dicer-1. Cell 2007, 130, 287-297. [CrossRef]

38. Yang, J.S.; Smibert, P.; Westholm, J.O.; Jee, D.; Maurin, T.; Lai, E.C. Intertwined pathways for Argonaute-mediated microRNA biogenesis in Drosophila. Nucleic Acids Res. 2014, 42, 1987-2002. [CrossRef]

39. Li, Z.; Rana, T.M. Therapeutic targeting of microRNAs: Current status and future challenges. Nat. Rev. Drug Discov. 2014, 13, 622-638. [CrossRef]

40. Wilczynska, A.; Bushell, M. The complexity of miRNA-mediated repression. Cell Death Differ. 2015, 22, 22-33. [CrossRef]

41. Pillai, R.S.; Bhattacharyya, S.N.; Filipowicz, W. Repression of protein synthesis by miRNAs: How many mechanisms? Trends Cell Boil. 2007, 17, 118-126. [CrossRef] [PubMed]

42. Hausser, J.; Syed, A.P.; Bilen, B.; Zavolan, M. Analysis of CDS-located miRNA target sites suggests that they can effectively inhibit translation. Genome Res. 2013, 23, 604-615. [CrossRef] [PubMed]

43. Brümmer, A.; Hausser, J. MicroRNA binding sites in the coding region of mRNAs: Extending the repertoire of post-transcriptional gene regulation. BioEssays 2014, 36, 617-626. [CrossRef] [PubMed] 
44. Lee, I.; Ajay, S.S.; Yook, J.I.; Kim, H.S.; Hong, S.H.; Kim, N.H.; Dhanasekaran, S.M.; Chinnaiyan, A.M.; Athey, B.D. New class of microRNA targets containing simultaneous 5'-UTR and 3'-UTR interaction sites. Genome Res. 2009, 19, 1175-1183. [CrossRef] [PubMed]

45. Kakumani, P.K.; Ponia, S.S.; Sood, V.; Chinnappan, M.; Banerjea, A.C.; Medigeshi, G.R.; Malhotra, P.; Mukherjee, S.K.; Bhatnagar, R.K. Role of RNA Interference (RNAi) in Dengue Virus Replication and Identification of NS4B as an RNAi Suppressor. J. Virol. 2013, 87, 8870-8883. [CrossRef]

46. Mukherjee, S.; Hanley, K.A. RNA interference modulates replication of dengue virus in Drosophila melanogaster cells. BMC Microbiol. 2010, 10, 127. [CrossRef] [PubMed]

47. Maharaj, P.D.; Widen, S.G.; Huang, J.; Wood, T.G.; Thangamani, S. Discovery of Mosquito Saliva MicroRNAs during CHIKV Infection. PLoS Negl. Trop. Dis. 2015, 9, e0003386. [CrossRef]

48. Shrinet, J.; Jain, S.; Jain, J.; Bhatnagar, R.K.; Sunil, S. Next Generation Sequencing Reveals Regulation of Distinct Aedes microRNAs during Chikungunya Virus Development. PLoS Negl. Trop. Dis. 2014, 8, e2616. [CrossRef]

49. Su, J.; Li, C.; Zhang, Y.; Yan, T.; Zhu, X.; Zhao, M.; Xing, D.; Dong, Y.; Guo, X.; Zhao, T. Identification of microRNAs expressed in the midgut of Aedes albopictus during dengue infection. Parasites Vectors 2017, 10, 971. [CrossRef]

50. Liu, Y.; Li, F.; Jia, Z.; Zhou, Y.; Yan, H.; Chen, X.; Zhang, H. Integrated analysis of miRNAs and transcriptomes in Aedes albopictus midgut reveals the differential expression profiles of immune-related genes during dengue virus serotype-2 infection. Insect Sci. 2016, 23, 377-385. [CrossRef]

51. Zhang, G.; Hussain, M.; O'Neill, S.L.; Asgari, S. Wolbachia uses a host microRNA to regulate transcripts of a methyltransferase, contributing to dengue virus inhibition in Aedes aegypti. Proc. Natl. Acad. Sci. USA 2013, 110, 10276-10281. [CrossRef] [PubMed]

52. Slonchak, A.; Hussain, M.; Torres, S.; Asgari, S.; Khromykh, A.A.; Williams, B. Expression of Mosquito MicroRNA Aae-miR-2940-5p Is Downregulated in Response to West Nile Virus Infection To Restrict Viral Replication. J. Virol. 2014, 88, 8457-8467. [CrossRef] [PubMed]

53. Dubey, S.K.; Shrinet, J.; Jain, J.; Ali, S.; Sunil, S. Aedes aegypti microRNA miR-2b regulates ubiquitin-related modifier to control chikungunya virus replication. Sci. Rep. 2017, 7, 17666. [CrossRef] [PubMed]

54. Isaacson, M.K.; Ploegh, H.L. Ubiquitination, Ubiquitin-like Modifiers, and Deubiquitination in Viral Infection. Cell Host Microbe 2009, 5, 559-570. [CrossRef] [PubMed]

55. Zhou, Y.; Liu, Y.; Yan, H.; Li, Y.; Zhang, H.; Xu, J.; Puthiyakunnon, S.; Chen, X. miR-281, an abundant midgut-specific miRNA of the vector mosquito Aedes albopictus enhances dengue virus replication. Parasites Vectors 2014, 7, 488. [CrossRef] [PubMed]

56. Yan, H.; Zhou, Y.; Liu, Y.; Deng, Y.; Chen, X. miR-252 of the Asian tiger mosquito Aedes albopictus regulates dengue virus replication by suppressing the expression of the dengue virus envelope protein. J. Med. Virol. 2014, 86, 1428-1436. [CrossRef] [PubMed]

57. Yen, P.-S.; James, A.; Li, J.-C.; Chen, C.-H.; Failloux, A.-B. Synthetic miRNAs induce dual arboviral-resistance phenotypes in the vector mosquito Aedes aegypti. Commun. Boil. 2018, 1, 11. [CrossRef] [PubMed]

58. Buchman, A.; Gamez, S.; Li, M.; Antoshechkin, I.; Li, H.-H.; Wang, H.-W.; Chen, C.-H.; Klein, M.J.; Duchemin, J.-B.; Paradkar, P.N.; et al. Engineered resistance to Zika virus in transgenic Aedes aegypti expressing a polycistronic cluster of synthetic small RNAs. Proc. Natl. Acad. Sci. USA 2019, 116, 3656-3661. [CrossRef] [PubMed]

59. Greer, D.S.; Zhang, Y.; Stewart, L.; Zhou, L.; Sun, G.; Gu, Z.; Kumar, S.; Zaremba, S.; Larsen, C.N.; Jen, W.; et al. Virus pathogen database and analysis resource (ViPR): A comprehensive bioinformatics database and analysis resource for the coronavirus research community. Viruses 2012, 4, 3209-3226. [CrossRef]

60. Pickett, B.E.; Sadat, E.L.; Zhang, Y.; Noronha, J.M.; Squires, R.B.; Hunt, V.; Liu, M.; Kumar, S.; Zaremba, S.; Gu, Z.; et al. ViPR: An open bioinformatics database and analysis resource for virology research. Nucleic Acids Res. 2012, 40, D593-D598. [CrossRef]

61. Hu, W.; Criscione, F.; Liang, S.; Tu, Z. MicroRNAs of two medically important mosquito species: Aedes aegypti and Anopheles stephensi. Insect Mol. Biol. 2015, 24, 240-252. [CrossRef] [PubMed]

62. Enright, A.J.; John, B.; Gaul, U.; Tuschl, T.; Sander, C.; Marks, D.S. MicroRNA targets in Drosophila. Genome Boil. 2003, 5, R1. [CrossRef] [PubMed]

63. Sturm, M.; Hackenberg, M.; Langenberger, D.; Frishman, D. TargetSpy: A supervised machine learning approach for microRNA target prediction. BMC Bioinform. 2010, 11, 292. [CrossRef] [PubMed] 
64. Rueda, A.; Barturen, G.; Lebron, R.; Gómez-Martín, C.; Alganza, A.; Oliver, J.L.; Hackenberg, M. sRNAtoolbox: An integrated collection of small RNA research tools. Nucleic Acids Res. 2015, 43, W467-W473. [CrossRef] [PubMed]

65. Quinlan, A.R.; Hall, I.M. BEDTools: A flexible suite of utilities for comparing genomic features. Bioinformatics 2010, 26, 841-842. [CrossRef] [PubMed]

66. Krüger, J.; Rehmsmeier, M. RNAhybrid: Microrna target prediction easy, fast and flexible. Nucleic Acids Res. 2006, 34, W451-W454. [CrossRef] [PubMed]

67. Zhang, X.; Aksoy, E.; Girke, T.; Raikhel, A.S.; Karginov, F.V. Transcriptome-wide microRNA and target dynamics in the fat body during the gonadotrophic cycle of Aedes aegypti. Proc. Natl. Acad. Sci. USA 2017, 114, E1895-E1903. [CrossRef] [PubMed]

68. Powers, A.M.; Logue, C.H. Changing patterns of chikungunya virus: Re-emergence of a zoonotic arbovirus. J. Gen. Virol. 2007, 88, 2363-2377. [CrossRef]

69. Tsetsarkin, K.A.; VanLandingham, D.L.; McGee, C.E.; Higgs, S.; Holmes, E.C. A Single Mutation in Chikungunya Virus Affects Vector Specificity and Epidemic Potential. PLoS Pathog. 2007, 3, e201. [CrossRef]

70. Vazeille, M.; Moutailler, S.; Coudrier, D.; Rousseaux, C.; Khun, H.; Huerre, M.; Thiria, J.; Dehecq, J.-S.; Fontenille, D.; Schuffenecker, I.; et al. Two Chikungunya Isolates from the Outbreak of La Reunion (Indian Ocean) Exhibit Different Patterns of Infection in the Mosquito, Aedes albopictus. PLoS ONE 2007, 2, e1168. [CrossRef]

71. Wahid, B.; Ali, A.; Rafique, S.; Idrees, M. Global expansion of chikungunya virus: Mapping the 64-year history. Int. J. Infect. Dis. 2017, 58, 69-76. [CrossRef] [PubMed]

72. Rupp, J.C.; Gebhart, N.N.; Sokoloski, K.J.; Hardy, R.W. Alphavirus RNA synthesis and non-structural protein functions. J. Gen. Virol. 2015, 96, 2483-2500. [CrossRef] [PubMed]

73. Vasilakis, N.; Weaver, S.C. Chapter 1 The History and Evolution of Human Dengue Emergence. Adv. Clin. Chem. 2008, 72, 1-76. [CrossRef]

74. Guzman, M.G.; Harris, E. Dengue. Lancet 2015, 385, 453-465. [CrossRef]

75. Dick, G.W. Zika virus. II. Pathogenicity and physical properties. Trans. R. Soc. Trop. Med. Hyg. 1952, 46, 521-534. [CrossRef]

76. Dick, G. Paper: Epidemiological notes on some viruses isolated in Uganda (Yellow fever, Rift Valley fever, Bwamba fever, West Nile, Mengo, Semliki forest, Bunyamwera, Ntaya, Uganda S and Zika viruses). Trans. $R$. Soc. Trop. Med. Hyg. 1953, 47, 13-48. [CrossRef]

77. Smithburn, K.C.; Taylor, R.M.; Rizk, F.; Kader, A. Immunity to Certain Arthropod-Borne Viruses among Indigenous Residents of Egypt. Am. J. Trop. Med. Hyg. 1954, 3, 9-18. [CrossRef]

78. Smithburn, K.C. Neutralizing antibodies against certain recently isolated viruses in the sera of human beings residing in East Africa. J. Immunol. 1952, 69, 223-234. [PubMed]

79. Smithburn, K.C.; Kerr, J.A.; Gatne, P.B. Neutralizing antibodies against certain viruses in the sera of residents of India. J. Immunol. 1954, 72, 248-257.

80. Smithburn, K.C. Neutralizing antibodies against arthropod-borne viruses in the sera of long-time residents of malaya and borneo1. Am. J. Epidemiol. 1954, 59, 157-163. [CrossRef]

81. MacNamara, F. Zika virus: A report on three cases of human infection during an epidemic of jaundice in Nigeria. Trans. R. Soc. Trop. Med. Hyg. 1954, 48, 139-145. [CrossRef]

82. Pond, W.L. Arthropod-borne virus antibodies in sera from residents of South-East Asia. Trans. R. Soc. Trop. Med. Hyg. 1963, 57, 364-371. [CrossRef]

83. Hammon, W.M.; Schrack, W.D.; Sather, G.E. Serological survey for a arthropod-borne virus infections in the Philippines. Am. J. Trop. Med. Hyg. 1958, 7, 323-328. [CrossRef] [PubMed]

84. Fagbami, A.H. Zika virus infections in Nigeria: Virological and seroepidemiological investigations in Oyo State. J. Hyg. 1979, 83, 213-219. [CrossRef] [PubMed]

85. Moore, D.L.; Causey, O.R.; Carey, D.E.; Reddy, S.; Cooke, A.R.; Akinkugbe, F.M.; David-West, T.S.; Kemp, G.E. Arthropod-borne viral infections of man in Nigeria, 1964-1970. Ann. Trop. Med. Parasitol. 1975, 69, 49-64. [CrossRef]

86. Olson, J.; Ksiazek, T.; Suhandiman. Triwibowo Zika virus, a cause of fever in Central Java, Indonesia. Trans. $R$. Soc. Trop. Med. Hyg. 1981, 75, 389-393. [CrossRef]

87. Simpson, D.I. Zika Virus Infection in Man. Trans. R. Soc. Trop. Med. Hyg. 1964, 58, 335-338. [CrossRef] 
88. Duffy, M.R.; Chen, T.-H.; Hancock, W.T.; Powers, A.M.; Kool, J.L.; Lanciotti, R.S.; Pretrick, M.; Marfel, M.; Holzbauer, S.; DuBray, C.; et al. Zika Virus Outbreak on Yap Island, Federated States of Micronesia. N. Engl. J. Med. 2009, 360, 2536-2543. [CrossRef]

89. Cao-Lormeau, V.-M.; Roche, C.; Teissier, A.; Robin, E.; Berry, A.-L.; Mallet, H.-P.; Sall, A.A.; Musso, D. Zika Virus, French Polynesia, South Pacific, 2013. Emerg. Infect. Dis. 2014, 20, 1085-1086. [CrossRef]

90. Oehler, E.; Watrin, L.; Larre, P.; Leparc-Goffart, I.; Lastere, S.; Valour, F.; Baudouin, L.; Mallet, H.P.; Musso, D.; Ghawche, F. Zika virus infection complicated by Guillain-Barre syndrome-Case report, French Polynesia, December 2013. Euro Surveill 2014, 19. [CrossRef]

91. Campos, G.S.; Bandeira, A.C.; Sardi, S.I. Zika Virus Outbreak, Bahia, Brazil. Emerg. Infect. Dis. 2015, 21, 1885-1886. [CrossRef] [PubMed]

92. Zanluca, C.; De Melo, V.C.A.; Mosimann, A.L.P.; Dos Santos, G.I.V.; Dos Santos, C.N.D.; Luz, K. First report of autochthonous transmission of Zika virus in Brazil. Memórias do Inst. Oswaldo Cruz 2015, 110, 569-572. [CrossRef] [PubMed]

93. World Health Organization. Zika Virus Microcephaly and Guillain-Barré Syndrome; World Health Organization: Geneva, Switzerland, 17 March 2016. Available online: http://apps.who.int/iris/bitstream/10665/204633/1/ zikasitrep_17Mar2016_eng.pdf (accessed on 10 June 2019).

94. Victora, C.G.; Schuler-Faccini, L.; Matijasevich, A.; Ribeiro, E.; Pessoa, A.; Barros, F.C. Microcephaly in Brazil: How to interpret reported numbers? Lancet 2016, 387, 621-624. [CrossRef]

95. Hennessey, M.; Fischer, M.; Staples, J.E. Zika Virus Spreads to New Areas - Region of the Americas, May 2015-January 2016. MMWR Morb. Mortal. Wkly. Rep. 2016, 65, 55-58. [CrossRef] [PubMed]

96. Faye, O.; Freire, C.C.M.; Iamarino, A.; Faye, O.; De Oliveira, J.V.C.; Diallo, M.; Zanotto, P.M.A.; Sall, A.A. Molecular Evolution of Zika Virus during Its Emergence in the 20th Century. PLoS Negl. Trop. Dis. 2014, 8, e2636. [CrossRef] [PubMed]

97. Petersen, L.R.; Jamieson, D.J.; Powers, A.M.; Honein, M.A. Zika Virus. N. Engl. J. Med. 2016, 374, $1552-1563$. [CrossRef] [PubMed]

98. Haddow, A.D.; Schuh, A.J.; Yasuda, C.Y.; Kasper, M.R.; Heang, V.; Huy, R.; Guzman, H.; Tesh, R.B.; Weaver, S.C. Genetic Characterization of Zika Virus Strains: Geographic Expansion of the Asian Lineage. PLoS Negl. Trop. Dis. 2012, 6, e1477. [CrossRef]

99. Etebari, K.; Asad, S.; Zhang, G.; Asgari, S. Identification of Aedes aegypti Long Intergenic Non-coding RNAs and Their Association with Wolbachia and Dengue Virus Infection. PLoS Negl. Trop. Dis. 2016, 10, e0005069. [CrossRef]

100. Hibio, N.; Hino, K.; Shimizu, E.; Nagata, Y.; Ui-Tei, K. Stability of miRNA 5 'terminal and seed regions is correlated with experimentally observed miRNA-mediated silencing efficacy. Sci. Rep. 2012, 2, 996. [CrossRef]

101. Pinzón, N.; Li, B.; Martinez, L.; Sergeeva, A.; Presumey, J.; Apparailly, F.; Seitz, H. microRNA target prediction programs predict many false positives. Genome Res. 2017, 27, 234-245. [CrossRef]

102. Hammell, M.; Long, D.; Zhang, L.; Lee, A.; Carmack, C.S.; Han, M.; Ding, Y.; Ambros, V. mirWIP: microRNA target prediction based on microRNA-containing ribonucleoprotein-enriched transcripts. Nat. Methods 2008, 5, 813-819. [CrossRef] [PubMed]

103. Kertesz, M.; Iovino, N.; Unnerstall, U.; Gaul, U.; Segal, E. The role of site accessibility in microRNA target recognition. Nat. Genet. 2007, 39, 1278-1284. [CrossRef] [PubMed]

104. Akbari, O.S.; Antoshechkin, I.; Amrhein, H.; Williams, B.; DiLoreto, R.; Sandler, J.; Hay, B.A. The developmental transcriptome of the mosquito Aedes aegypti, an invasive species and major arbovirus vector. G3 (Bethesda) 2013, 3, 1493-1509. [CrossRef] [PubMed]

105. Li, S.; A Mead, E.; Liang, S.; Tu, Z. Direct sequencing and expression analysis of a large number of miRNAs in Aedes aegypti and a multi-species survey of novel mosquito miRNAs. BMC Genom. 2009, 10, 581. [CrossRef] [PubMed]

106. Mayoral, J.G.; Etebari, K.; Hussain, M.; Khromykh, A.A.; Asgari, S. Wolbachia Infection Modifies the Profile, Shuttling and Structure of MicroRNAs in a Mosquito Cell Line. PLoS ONE 2014, 9, e96107. [CrossRef] [PubMed]

107. Scheel, T.K.H.; Luna, J.M.; Liniger, M.; Nishiuchi, E.; Rozen-Gagnon, K.; Shlomai, A.; Auray, G.; Gerber, M.; Fak, J.; Keller, I.; et al. A broad RNA virus survey reveals both miRNA dependence and functional sequestration. Cell Host Microbe 2016, 19, 409-423. [CrossRef] [PubMed] 
108. Trobaugh, D.W.; Klimstra, W.B. MicroRNA Regulation of RNA Virus Replication and Pathogenesis. Trends Mol. Med. 2017, 23, 80-93. [CrossRef]

109. Trobaugh, D.W.; Gardner, C.L.; Sun, C.; Haddow, A.D.; Wang, E.; Chapnik, E.; Mildner, A.; Weaver, S.C.; Ryman, K.D.; Klimstra, W.B. RNA viruses can hijack vertebrate microRNAs to suppress innate immunity. Nature 2014, 506, 245-248. [CrossRef]

110. Huang, J.; Wang, F.; Argyris, E.; Chen, K.; Liang, Z.; Tian, H.; Huang, W.; Squires, K.; Verlinghieri, G.; Zhang, H. Cellular microRNAs contribute to HIV-1 latency in resting primary CD4+ T lymphocytes. Nat. Med. 2007, 13, 1241-1247. [CrossRef]

111. Nathans, R.; Chu, C.-Y.; Serquina, A.K.; Lu, C.-C.; Cao, H.; Rana, T.M. Cellular MicroRNA and P Bodies Modulate Host-HIV-1 Interactions. Mol. Cell 2009, 34, 696-709. [CrossRef]

112. Wen, B.-P.; Dai, H.-J.; Yang, Y.-H.; Zhuang, Y.; Sheng, R. MicroRNA-23b Inhibits Enterovirus 71 Replication through Downregulation of EV71 VPl Protein. Intervirology 2013, 56, 195-200. [CrossRef] [PubMed]

113. Zheng, Z.; Ke, X.; Wang, M.; He, S.; Li, Q.; Zheng, C.; Zhang, Z.; Liu, Y.; Wang, H. Human MicroRNA hsa-miR-296-5p Suppresses Enterovirus 71 Replication by Targeting the Viral Genome. J. Virol. 2013, 87, 5645-5656. [CrossRef]

114. Bai, X.T.; Nicot, C. miR-28-3p Is a Cellular Restriction Factor That Inhibits Human T Cell Leukemia Virus, Type 1 (HTLV-1) Replication and Virus Infection*. J. Boil. Chem. 2015, 290, 5381-5390. [CrossRef] [PubMed]

115. Lecellier, C.H.; Dunoyer, P.; Arar, K.; Lehmann-Che, J.; Eyquem, S.; Himber, C.; Saïb, A.; Voinnet, O. A cellular microRNA mediates antiviral defense in human cells. Science 2005, 308, 557-560. [CrossRef] [PubMed]

116. Conrad, K.D.; Giering, F.; Erfurth, C.; Neumann, A.; Fehr, C.; Meister, G.; Niepmann, M. microRNA-122 Dependent Binding of Ago2 Protein to Hepatitis C Virus RNA Is Associated with Enhanced RNA Stability and Translation Stimulation. PLoS ONE 2013, 8, e56272. [CrossRef]

117. Jopling, C.L.; Yi, M.; Lancaster, A.M.; Lemon, S.M.; Sarnow, P. Modulation of Hepatitis C Virus RNA Abundance by a Liver-Specific MicroRNA. Science 2005, 309, 1577-1581. [CrossRef] [PubMed]

(C) 2019 by the authors. Licensee MDPI, Basel, Switzerland. This article is an open access article distributed under the terms and conditions of the Creative Commons Attribution (CC BY) license (http://creativecommons.org/licenses/by/4.0/). 